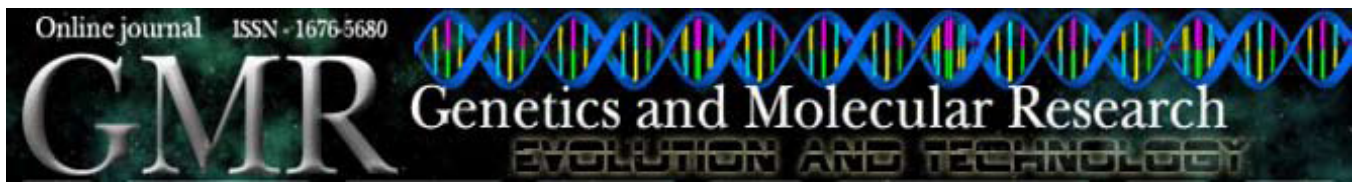

\title{
RAPD assay of wild-type olives in Turkey
}

\author{
M. Sesli ${ }^{1}$ and E.D. Yeğenoğlu ${ }^{2}$ \\ ${ }^{1}$ College of Tobacco Expertise, Celal Bayar University, \\ Republic of Turkey, Akhisar, Manisa, Turkey \\ ${ }^{2}$ Akhisar Vocational College, Celal Bayar University, \\ Republic of Turkey, Akhisar, Manisa, Turkey \\ Corresponding author: M. Sesli \\ E-mail: meltem.sesli@bayar.edu.tr
}

Genet. Mol. Res. 9 (2): 966-972 (2010)

Received February 2, 2010

Accepted March 15, 2010

Published May 25, 2010

DOI 10.4238/vol9-2gmr783

\begin{abstract}
Genetic similarities and distances between wild-type olives in Turkey were studied using an RAPD-PCR assay. Seven wild olive tree samples were collected from villages in Manisa and Izmir provinces. Genomic DNA was extracted from young leaves and the RAPD-PCR assay was used to generate RAPD markers. Sixty-five random primers obtained from Operon Technologies were tested for the assay (OP-A 1-20, OP-I 1-20, OP-Q 1-20, and OP-J 1-5). Thirtytwo of these primers yielded 115 highly polymorphic bands. The mean number of usable bands per primer for all the samples was 3.59. The genetic distance values ranged from 0.1498 to 0.6845 , and genetic similarity values varied from 0.8609 to 0.5043 . We found that the closest samples based on their genetic distance and similarity values were from Harlak and Sabancilar; the most distant samples were from Bornova and Bademli.
\end{abstract}

Key words: RAPD; Wild olives; Genetic analysis 


\section{INTRODUCTION}

The olive tree is one of the oldest agriculturally important trees of humankind. It is believed that the cultivated type olives derived from oleasters or wild olives of the Mediterranean Basin and that they are spread throughout the world through human activities (Besnard et al., 2001). Olea europaea spp europaea consists of two subspecies; these are wild olives (Olea europaea oleaster) and the cultivated olives named Olea europaea sativa (Mendilcioglu, 1999). Wild-type olives are important for improvement studies because of their high degree of resistance against unfavorable environmental conditions and diseases. For this purpose, wild olives are a good source for understanding the mechanism of disease resistance/susceptibility or selection of disease-resistant plants.

Identification between and within olive types could be determined by morphological or phenotypic traits, but these traits are severely affected by environmental conditions and difficult to evaluate (Claros et al., 2000). However, DNA-based markers are not influenced by environmental conditions, and they allow direct scanning of the plant genome (MartinsLopes et al., 2007; Doveri et al., 2008). Genetic polymorphism of the plants can be detected by many different DNA-based marker methods such as RFLPs (Besnard and Berville, 2000), AFLPs (Sanz-Cortés et al., 2003; Owen et al., 2005), SSRs (Rallo et al., 2000; Cipriani et al., 2002; Belaj et al., 2004), ISSRs (Gemas et al., 2004), and random amplified polymorphic DNAs (RAPDs) (Belaj et al., 2001; Besnard et al., 2001; La Rosa et al., 2003; Wu et al., 2004; Ganino et al., 2007). Additionally, chloroplast and mitochondrial DNA analyses are helpful in examining the genetic structure of plants (Besnard et al., 2002).

DNA-based markers used in breeding and genetic studies of agriculturally important plants have specific advantages in terms of saving time compared to classical breeding methods, where they are not affected by environmental factors and produce results in a short time. RAPD markers, being one of the DNA-based markers, enable random sections of DNA to be rapidly reproduced using short polynucleotide primers. The polymerase chain reaction (PCR)-based RAPD assay was developed by Welsh and McClelland (1990) and Williams et al. (1990), and the RAPD markers are commonly used for genetic classification and determination of genetic diversity among both wild and cultivated olive types (Belaj et al., 2001; Besnard et al., 2001; La Rosa et al., 2003; Wu et al., 2004; Ganino et al., 2007).

Olives are raised in Turkey in a very wide range from the Aegean and Mediterranean and Marmara to Black Sea regions because these regions have favorable climatic conditions for olive breeding. The Aegean region has the most suitable breeding conditions among these regions, and olives are one of the commonly cultivated agricultural products in Manisa and Izmir provinces of the Aegean region; Izmir has a production share of $12.57 \%$ and Manisa $11.59 \%$ (MOARA, 2006; Sesli and Tokmakoglu, 2006).

Establishing genetic variation within and between olive types is a considerable part of cultivar sampling and is a support in determining the genetic relationships among wild types and their cultivated type relatives. Besides, knowledge of the genetic relationships between wild olives and their cultivated relatives is necessary to improve genetic resources and our understanding of their evolutionary background (Kockar and Ilikci, 2003; Baldoni et al., 2006). Presently, DNA-based markers give us a chance to make direct comparison of the organisms at the molecular level, as the use of DNA-based molecular markers has become popular in plant breeding as well as olives along with the other agriculturally important plants (Claros et al., 2000).

The primary objective of this study was to examine the genetic similarity and distance 
between wild olive samples from Izmir and Manisa provinces of the Aegean region. The wild olive samples were obtained from different villages of Manisa and Izmir. The other objective was to gain any information on the present genetic state of wild olives in these provinces.

\section{MATERIAL AND METHODS}

\section{Plant material}

Samplings of Olea europaea oleasters were obtained from villages of Manisa and Izmir. A total of 7 samples were chosen among saplings from healthy and uniform young trees. Fresh leaves were collected and stored in liquid nitrogen until DNA extraction. Table 1 shows the wild olives used in this study and the provinces supplying them.

\begin{tabular}{ll} 
Table 1. Provinces supplying wild olives. & \\
\hline Type of olive & Provinces in Turkey \\
\hline Wild 1 & Caglak, Akhisar, Manisa \\
Wild 2 & Harlak, Akhisar, Manisa \\
Wild 3 & Sabancilar, Akhisar, Manisa \\
Wild 4 & Bornova, Izmir, Bornova \\
Wild 5 & Yayakirildik, Akhisar, Manisa \\
Wild 6 & Bademi, Dikili, Izmir \\
Wild 7 & Karacakas, Soma, Manisa \\
\hline
\end{tabular}

\section{DNA extraction}

Genomic DNA was extracted from young leaves using the Doyle and Doyle method (1987). One gram of olive leaves was ground using a mortar and pestle pre-chilled with liquid nitrogen, and $700 \mu \mathrm{L}$ preheated CTAB extraction buffer (2\% CTAB, $20 \mathrm{mM}$ EDTA, 1.4 $\mathrm{M} \mathrm{NaCl}, 100 \mathrm{mM}$ Tris-HCl, $\mathrm{pH} 8.0,2 \% \beta$-mercaptoethanol) was added to the frozen ground leaves, mixing several times by gentle inversion. Samples with CTAB buffer were incubated for $30 \mathrm{~min}$ at $65^{\circ} \mathrm{C}$. Tubes were mixed by inversion every $5 \mathrm{~min}$ during incubation. After removal from the hot bath, tubes were cooled down and $700 \mu \mathrm{L}$ cold chloroform:isoamyl alcohol (24:1) was then added followed by vigorous mixing. Tubes were centrifuged at 10,000 rpm for $10 \mathrm{~min}$ at $4^{\circ} \mathrm{C}$. Supernatants were transferred to new tubes; $600 \mu \mathrm{L}$ cold chloroform:isoamyl alcohol (24:1) was added followed by mixing by gentle inversion for $5 \mathrm{~min}$. Samples were centrifuged at $10,000 \mathrm{rpm}$ for $10 \mathrm{~min}$ at $4^{\circ} \mathrm{C}$. Supernatants were transferred to fresh tubes containing $10 \mathrm{M}$ ammonium acetate and $3 \mathrm{M}$ sodium acetate. A volume of $500 \mu \mathrm{L}$ cold isopropanol was added and the contents mixed by shaking very gently for DNA precipitation. Precipitated DNA was removed with a pipette and washed with $70 \%$ ethanol. DNA was dried and resuspended in $50 \mu \mathrm{L}$ EDTA. The crude DNA sample was treated with $1 \mu \mathrm{L}$ RNAase A for $10 \mathrm{~min}$ at $37^{\circ} \mathrm{C}$ (final concentration $10 \mu \mathrm{g} / \mu \mathrm{L}$ ).

The determination of DNA quality and concentration in samples was performed by both spectrophotometric analysis and running on $0.8 \%$ agarose gels. Optical density ratios from spectrophotometric analysis were evaluated and only good-quality DNA samples were used in PCR (Wu et al., 2004).

A total of 65 primers from the kits OP-A 1-20, OP-I 1-20, OP-Q 1-20, and OP-J 1-5 
(Operon Technologies, Alameda, CA, USA) were used for RAPD-PCR assay. PCR was performed on an Eppendorf MasterCycler Thermal Cycler in a total volume of $25 \mu \mathrm{L}$. The PCR mix included $25 \mathrm{ng}$ template DNA, $2.42 \mu \mathrm{L}$ 10X PCR buffer with $\mathrm{MgCl}_{2}$ (Sigma), $0.44 \mu \mathrm{L}$ dNTP (Sigma), $1 \mu \mathrm{M}$ primer, and $0.13 \mu \mathrm{L}$ Taq DNA polymerase (Sigma). The amplification reactions were carried out for $60 \mathrm{~s}$ at $94^{\circ} \mathrm{C}$ as an initial denaturation.

The PCR program comprised 35 cycles of $20 \mathrm{~s}$ at $94^{\circ} \mathrm{C}$ for denaturation, $20 \mathrm{~s}$ at $35^{\circ} \mathrm{C}$ for annealing, and $20 \mathrm{~s}$ at $72^{\circ} \mathrm{C}$ for extension, and a final extension was performed at $72^{\circ} \mathrm{C}$ for $5 \mathrm{~min}$.

Amplification products were loaded onto $1.5 \%$ agarose gels (Sigma) in $0.5 \mathrm{X}$ TBE buffer with $0.5 \mu \mathrm{g} / \mathrm{mL}$ ethidium bromide at $100 \mathrm{~V}$ constant voltage. For evaluating the base pair size of bands, a DNA ladder (Fermentas) was loaded on the first lane of each gel. After the separation of PCR products by agarose gel electrophoresis, gels were visualized with Photo Print (Vilber Lourmat, France) imaging system and analyzed by the BioOne D++ software (Vilber Lourmat, France). The RAPD bands were scored as 1 for present or 0 for absent; only clear bands were scored for the construction of the data matrix. The dendrogram was constructed using the POPGEN32 program according to Nei's coefficient (1972), and the UPGMA algorithm (unweighted pair-group method with arithmetic mean) was chosen for hierarchical clustering analysis (Sneath and Sokal, 1973; Yeh et al., 1999).

\section{RESULTS AND DISCUSSION}

A total of 32 primers of 65 yielded clear and stable bands, and a total of 115 loci were detected. The average number of evaluable bands per primer for all the samples was 3.59. A total of 50 bands were obtained with OP-A primers. Primers OP-A 9 and OP-A 10 showed the highest number of RAPD bands (16 and 11, respectively). No bands were obtained using primers OP-A 8, OP-A 17 and OP-A 18. However, 22 bands were obtained with the OP-Q primer set, and the most bands were produced by OP-Q 11 with a total of 11 bands. No bands were obtained with primers OP-Q 3, OP-Q 4, OP-Q 5, OP-Q 6, OP-Q 7, OP-Q 8, OP-Q 9, OP-Q 10. Scorable bands were not obtained with primers OP-I 4, OP-I 14, OP-I 15, OP-I 16, and OP-I 17 for the OP-I primer set; 43 bands were determined and the maximum number of loci was 14 with OP-I 14, whereas the minimum number of loci was found to be 2 with OP-I 15 . There were no scorable bands with primers OP-J 1 to OP-J 5. The RAPD profiles obtained with the OP-I 17 primer are shown in Figure 1.

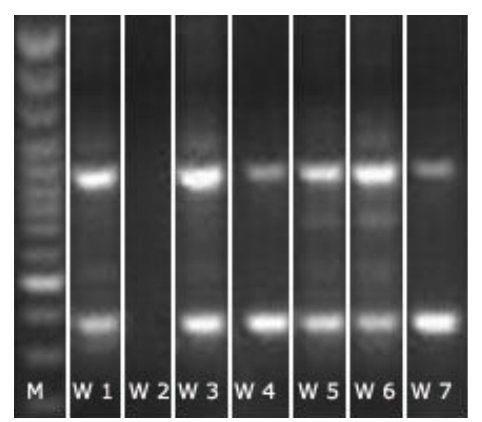

Figure 1. RAPD patterns with the use of primer OP-I 17. M = marker; W 1 (wild 1) = Caglak; W 2 (wild 2) = Harlak; W 3 (wild 3) = Sabancilar; W 4 (wild 4) = Bornova; W 5 (wild 5) = Yayakirildik; W 6 (wild 6) = Bademli; W 7 (wild 7) $=$ Karacakas. 
The matrix shown in Table 2 was obtained using Nei's genetic distance coefficient in the POPGEN32 software for determining the genetic similarities and distances between wild olives in the study. As a result of cluster analysis conducted using the UPGMA method, the dendrogram of different wild olive types was constructed as shown in Figure 2.

Table 2. Nei's genetic similarity and distance values obtained for wild-type olives (Nei, 1972).

\begin{tabular}{lccccccc}
\hline & Wild 1 & Wild 2 & Wild 3 & Wild 4 & Wild 5 & Wild 6 & Wild 7 \\
\hline Wild 1 & $* * * *$ & 0.7478 & 0.7130 & 0.5826 & 0.6609 & 0.5913 & 0.5739 \\
Wild 2 & 0.2906 & $* * * *$ & 0.8609 & 0.7130 & 0.7913 & 0.6522 & 0.7043 \\
Wild 3 & 0.3382 & 0.1498 & $* * * *$ & 0.6783 & 0.7913 & 0.6348 & 0.6870 \\
Wild 4 & 0.5402 & 0.3382 & 0.3882 & $* * * *$ & 0.6435 & 0.5043 & 0.5913 \\
Wild 5 & 0.4142 & 0.2341 & 0.2341 & 0.4409 & $* * *$ & 0.6696 & 0.6870 \\
Wild 6 & 0.5254 & 0.4274 & 0.4545 & 0.6845 & 0.4011 & 0.6000 \\
Wild 7 & 0.5553 & 0.3505 & 0.3755 & 0.5254 & 0.3755 & 0.5108 & $* * * *$ \\
\hline
\end{tabular}

*Nei's genetic identity (above diagonal) and genetic distance (below diagonal).

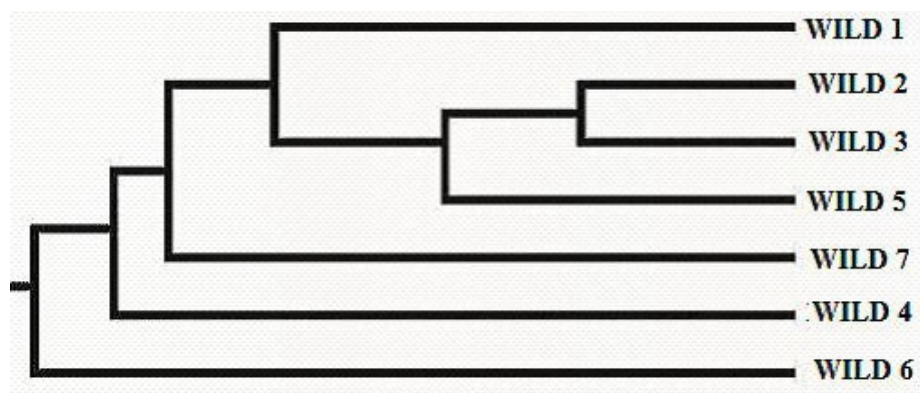

Figure 2. Dendrogram constructed for all the primers studied. For explanations of WILD 1-7, see Table 1.

The data matrix was constructed for samples common in all evaluable primers yielding bands while developing the dendrogram and matrix of genetic distances and similarities. Genetic distance values varied between 0.1498 (wild 2 and wild 3) and 0.6845 (wild 4 and wild 6). Thus, samples closest to each other are wild 2 and wild 3, and samples most distant from each other are wild 4 and wild 6 , based on their genetic distance values.

Genetic similarity values varied between 0.8609 (wild 3 and wild 2) and 0.5043 (wild 6 and wild 4). Thus, samples with the closest genetic similarities are wild 3 and wild 2, and samples with the most distant genetic similarities are wild 6 and wild 4. Genetic similarity values and genetic distance values were in full compliance with each other.

It is very important to characterize wild forms of olives because of their intended use in olive improvement studies. In this study, OP-A, OP-Q and OP-I primer sets generated scorable bands in wild olive types, but 5 primers from the OP-J kit (OP-J 1 to OP-J 5) did not generate RAPD bands. The RAPD bands were found to be highly polymorphic as mentioned in other studies. The high degree of polymorphism obtained indicated a potential for selection and availability as a genetic source (Bandelj et al., 2002).

Belaj et al. (2001) reported a high genetic polymorphism rate of olive varieties grown in the Mediterranean basin using RAPD assay with 46 arbitrary primers. The results of this study were promising in our first experiments with OP-A, OP-Q and OP-I primer kits. A more 
detailed study with larger numbers of samples using such primer sets could have a significant potential in the determination of genetic markers, due to the number of bands and high polymorphism in wild samples.

It is important to protect wild types of olives particular to regions in terms of breeding; therefore, it is important to study and determine the genetic structures of these olives. Determining genetic markers and supporting such markers with data on phenotypic and morphologic characteristics would have a substantial effect on olive breeding and the identification of olive types (Bernardi et al., 2001). However, changes that may be observed in phenotypic variations despite genetic similarities would probably be associated with environmental conditions and cultivation applications altering genetic expression (Wiesman et al., 1998).

RAPD markers are frequently used in determining the genetic structure of olive trees. RAPD markers are also beneficial as the initial step in displaying a genomic map for plants with unknown or much less known genetic ranges (Wu et al., 2004). The examination of genetic relationships between wild and cultivated types led to the construction of a genetic map of the olive tree and determination of suitable genetic markers for olive improvement studies.

\section{ACKNOWLEDGMENTS}

Research supported by the Turkish Republic State Planning Organization. Dr. Meltem Sesli would like to thank Prof. Dr. W. Friedt and his team (Dr. Heike Köhler and Thomas Röder) from whom she received a course on molecular markers (Justus Liebig University Faculty of Agriculture, Giessen, Germany).

\section{REFERENCES}

Baldoni L, Tosti N, Ricciolini C, Belaj A, et al. (2006). Genetic structure of wild and cultivated olives in the central Mediterranean basin. Ann. Bot. 98: 935-942.

Bandelj D, Jakse J and Javornik B (2002). DNA fingerprinting of olive varieties by microsatellite markers. Food Technol. Biotechnol. 40: 185-190.

Belaj A, Trujillo I, de la Rosa R, Rallo L, et al. (2001). Polymorphism and discrimination capacity of randomly amplified polymorphic markers in an olive germplasm bank. J. Am. Soc. Hort. Sci. 126: 64-71.

Belaj A, Cipriani G, Testolin R, Rallo L, et al. (2004). Characterization and identification of the main Spanish and Italian olive cultivars by simple-sequence-repeat markers. Hort. Sci. 39: 1557-1561.

Bernardi R, Manzo M, Durante M, Petrucceli R, et al. (2001). Molecular markers for cultivar characterization in Olea europaea. Acta Hort. 586: 97-100.

Besnard G and Berville A (2000). Multiple origins for Mediterranean olive (Olea europaea L. ssp. europaea) based upon mitochondrial DNA polymorphisms. C. R. Acad. Sci III 323: 173-181.

Besnard G, Baradat P and Bervillé A (2001). Genetic relationships in the olive (Olea europaea L.) reflect multilocal selection of cultivars. Theor. Appl. Genet. 102: 221-258.

Besnard G, Khadari B, Baradat P and Berville A (2002). Olea europaea (Oleaceae) phylogeography based on chloroplast DNA polymorphism. Theor. Appl. Genet. 104: 1353-1361.

Cipriani G, Marrazzo MT, Marconi R, Cimato A, et al. (2002). Microsatellite markers isolated in olive (Olea europaea L.) are suitable for individual fingerprinting and reveal polymorphism within ancient cultivars. Theor. Appl. Genet. 104: 223-228.

Claros GM, Crespillo R, Agilar MI and Canovas FM (2000). DNA fingerprinting and classification of geographically related genotypes of olive-tree (Olea europaea L.). Euphytica 116: 131-142.

Doveri S, Gil FS, Díaz A, Reale S, et al. (2008). Standardization of a set of microsatellite markers for use in cultivar identification studies in olive (Olea europaea L.). Sci. Horticul. 116: 367-373.

Doyle JJ and Doyle JL (1987). A rapid DNA isolation procedure from small quantities of fresh leaf tissue. Phytochem. Bull. 19: 11-15. 
Ganino T, Beghè D, Valenti S, Nisi R, et al. (2007). RAPD and SSR markers for characterization and identification of ancient cultivars of Olea europaea L. in the Emilia region, Northern Italy. Genet. Res. Crop Evol. 54: 1531-1540.

Gemas VJV, Almadanim MC, Tenreiro R, Martins A, et al. (2004). Genetic diversity in the Olive tree (Olea europaea L. subsp. europaea) cultivated in Portugal revealed by RAPD and ISSR markers. Genet. Res. Crop Evol. 51: 501-511.

Kockar F and Ilikci R (2003). Investigations of genetic variation between olive (Olea europaea L.) cultivars using arbitrarily primed polymerase chain reaction (AP-PCR). Z. Naturforsch. C 58: 837-842.

La Rosa R, Angiolillo A, Guerrero C, Pellegrini M, et al. (2003). A first linkage map of olive (Olea europaea L.) cultivars using RAPD, AFLP, RFLP and SSR markers. Theor. Appl. Genet. 106: 1273-1282.

Martins-Lopes P, Lima-Brito J, Gomes S, Meirinhos J, et al. (2007). RAPD and ISSR molecular markers in Olea europaea L.: Genetic variability and molecular cultivar identification. Genet. Res. Crop Evol. 54: 117-128.

Mendilcioglu K (1999). Olive. In: Subtropical Climate Fruits. Publications of Faculty of Agriculture. Ege University, Bornova-Izmir, 1-8.

MOARA (2006). Ministry of Agriculture and Rural Affairs of Republic of Turkey, Farmers Training series 14. Olive Breeding, Ankara, 7.

Nei M (1972). Genetic distance between populations. Am. Nat. 106: 283-292.

Owen CA, Bita EC, Banilas G, Hajjar SE, et al. (2005). AFLP reveals structural details of genetic diversity within cultivated olive germplasm from the Eastern Mediterranean. Theor. Appl. Genet. 110: 1169-1176.

Rallo L, Dorado G and Martín A (2000). Development of simple sequence repeats (SSRs) in olive tree (Olea europaea L.). Theor. Appl. Genet. 101: 984-989.

Sanz-Cortés F, Parfitt DE, Romero C, Struss D, et al. (2003). Intraspecific olive diversity assessed with AFLP. Plant Breed. 122: 173-177.

Sesli M and Tokmakoğlu A (2006). Olive Production and Akhisar. Sectoral Mag. 31: 42.

Sneath PHA and Sokal RR (1973). Numerical Taxonomy. W.H. Freeman and Co., San Francisco, 230-234.

Welsh J and McClelland M (1990). Fingerprinting genomes using PCR with arbitrary primers. Nucleic Acids Res. 18: 7213-7218.

Wiesman Z, Lavee NAS and Quebedeaux B (1998). Molecular characterization of common olive varieties in Israel and the West Bank using randomly amplified polymorphic DNA (RAPD) markers. J. Am. Soc. Hort. Sci. 123: 837-841.

Williams JG, Kubelik AR, Livak KJ, Rafalski JA, et al. (1990). DNA polymorphisms amplified by arbitrary primers are useful as genetic markers. Nucleic Acids Res. 18: 6531-6535.

Wu SB, Collins G and Sedgley M (2004). A molecular linkage map of olive (Olea europaea L.) based on RAPD, microsatellite, and SCAR markers. Genome 47: 26-35.

Yeh FC, Yang RC, Boyle TBJ, Ye ZH, et al. (1999). POPGENE, the User-Friendly Shareware for Population Genetic Analysis. Molecular Biology and Biotechnology Centre, University of Alberta, Alberta. 